\title{
PERBANDINGAN KINERJA REKSADANA SYARIAH DAN PASAR JII MENGGUNAKAN METODE TREYNOR (Studi Kasus Reksadana Saham Syariah, Reksadana Syariah Pendapatan Tetap dan Reksadana Syariah Pendapatan Campuran Periode 2011-2015)1]
}

\author{
Sarah Aulia Rahma \\ Mahasiswa Program Studi Ekonomi Islam-Fakultas Ekonomi dan Bisnis-Universitas Airlangga \\ Email: sarah.aulia-12@feb.unair.ac.id \\ Ari Prasetyo \\ Departemen Ekonomi Syariah-Fakultas Ekonomi dan Bisnis-Universitas Airlangga \\ Email:ari.prasetyo@feb.unair.ac.id
}

\begin{abstract}
:
This research aims to find out the comparison between the performance of Islamic mutual funds of stock, Islamic mutual funds of fixed income and combined Islamic mutual funds with the market (Jakarta Islamic Index) as benchmark by using Treynor method. The method of this measuring calculates upon the risk factors and the return rate of those three kinds of Islamic mutual fund and benchmark. This research uses 21 samples of Islamic mutual fund in Indonesia which consist of seven Islamic mutual funds of stock, seven Islamic mutual funds of fixed income and seven combined Islamic mutual. The approach used is a quantitative approach with the analysis technique of ANOVA. The result of this study shows that there is no difference between the performances of Islamic mutual funds of stock, Islamic mutual funds of fixed income, combined Islamic mutual funds and the market on period of January 2011 until December 2015.
\end{abstract}

Keywords : Islamic Mutual Funds of Stock, Islamic Mutual Funds of Fixed Income, Combined Islamic Mutual Funds, Treynor Method.

\section{PENDAHULUAN}

\section{Latar Belakang}

Perekonomian dunia mengalami perkembangan yang sangat pesat, baik dari segi sistem maupun produknya. Hampir semua negara juga mengalami hal yang serupa, tidak terkecuali Indonesia. Bertambahnya produk-produk baru dari lembaga keuangan seperti perbankan, pasar modal berdampak pula pada peningkatan pemasukan negara.

Aktivitas muamalah diperbolehkan selama tidak ada dalil yang melarangnya. Salah satunya adalah dalam hal investasi. Manusia diperbolehkan untuk berinvestasi selama tidak mengandung riba, maysir, gharar dan tidak melanggar syariat-syariat Islam, baik pada akad 1] Jurnal ini merupakan bagian dari skripsi dari Sarah Aulia Rahma, NIM: 041211433066, yang diuji pada tanggal 8 Agustus 2016 maupunproduknya. Investasi dapat dilakukan di mana saja, salah satunya di pasar modal.

Pasar modal dapat dikategorikan menjadi dua macam, yaitu pasar modal konvensional dan pasar modal syariah. Pasar modal konvensional berasumsi bahwa segala sesuatu yang menguntungkan diperbolehkan. Pasar modal syariah secara prinsip sudah sangat konvensional karena menggunakan instrumen dan prinsip syariah.

Soemitra (2009:111) menyatakan bahwa:

Pasar modal syariah secara sederhana dapat diartikan sebagai berbeda dengan pasar modal 
Rahma, et al/Jurnal Ekonomi Syariah Teori dan Terapan Vol. 4 No. 5 Mei 2017: 410-423; PERBANDINGAN KINERJA REKSADANA SYARIAH DAN PASAR JII MENGGUNAKAN METODE TREYNOR (Studi Kasus Reksadana Saham Syariah, Reksadana Syariah Pendapatan Tetap dan Reksadana Syariah Pendapatan Campuran Periode 2011-2015)

pasar modal yang menerapkan prinsip-prinsip syariah dalam kegiatan transaksi ekonomi hal-hal yang dilarang seperti: riba, perjudian, dan spekulasi.

Berinvestasi di pasar modal syariah pun tidak menjamin bahwa tidak ada risiko yang ditimbulkan karena pada dasarnya apapun yang diperbuat pasti ada risiko yang harus ditanggung. Hal tersebut sesuai dengan kaidah syariah tentang imbal hasil dan resiko adalah "alghunmu bil ghumri", artinya resiko akan selalu menyertai setiap ekspetasi return (investasi) atau imbal hasil (Dzajuli, 2006:103).

Reksadana merupakan salah satu unsur penting dalam pasar modal di Indonesia, termasuk juga reksadana syariah. Anshori (2008:72) mengatakan bahwa:

Reksadana syariah adalah reksadana yang beroperasi menurut ketentuan dan prinsip syariah Islam, baik dalam bentuk akad antara pemodal sebagai pemilik harta (shahib al$\mathrm{mal} / \mathrm{rabb}$ al-mal), maupun antara manajer investasi sebagai wakil shahib al-mal dengan pengguna investasi.

Berdasarkan portofolionya, reksadana syariah mempunyai beberapa jenis antara lain; reksadana pasar vang syariah, reksadana syariah pendapatan tetap, reksadana saham syariah, reksadana syariah pendapatan campuran.

Cara yang paling mudah bagi investor untuk menentukan perusahaan investasi mana yang akan dipilih adalah dengan melihat NAB. Reksadana syariah sangat erat hubungannya dengan NAB sehingga hal tersebut menjadi alasan kuat investor ketika ingin menanamkan dananya pada suatu perusahaan. Akan tetapi, dengan mengetahui NAB saja tidaklah cukup sehingga diperlukan adanya kinerja portofolio reksadana syariah yang sesuai.

Untuk melihat kinerja portofolio reksadana syariah, dibutuhkan suatu alat pengukuran untuk mengukur kinerja tersebut. Metode Treynor merupakan salah satu metode pengukuran kinerja portofolio reksadana syariah.

Manurung (2007:131) menyatakan bahwa pengukuran Treynor mengasumsikan bahwa sangat diversifikasi, sehingga risiko yang ada dalam portofolio hanyalah risiko sistematik. Dengan mempertimbangkan risiko sistematik saja, hasil yang didapat dengan perhitungan Treynor dianggap lebih maksimal. Investor yang memiliki portofolio yang terdiversifikasi dengan baik lebih cocok menggunakan metode Treynor sebagai alat pengukur kinerja portofolio apabila dibandingkan dengan metode yang lain.

Membandingkan kinerja antar reksadana syariah dengan kinerja pasar perlu dilakukan untuk mengetahui sehat tidaknya perusahaan investasi yang dipilih oleh investor dalam reksadana syariah. Pasar yang dijadikan acuan dalam penelitan ini adalah pasar modal syariah Indonesia yaitu JII (Jakarta Islamic Index) yang merupakan bursa saham syariah yang memfasilitasi perdagangan perusahaan publik yang dijalankan sesuai prinsip syariah. 
Rahma, et al/Jurnal Ekonomi Syariah Teori dan Terapan Vol. 4 No. 5 Mei 2017: 410-423; PERBANDINGAN KINERJA REKSADANA SYARIAH DAN PASAR JII MENGGUNAKAN METODE TREYNOR (Studi Kasus Reksadana Saham Syariah, Reksadana Syariah Pendapatan Tetap dan Reksadana Syariah Pendapatan Campuran Periode 2011-2015)

Berdasarkan latar belakang di atas, maka penelitian ini akan mengkaji dan membandingkan kinerja antara reksadana saham syariah, reksadana syariah pendapatan tetap dan campuran dengan menggunakan metode Treynor yang kemudian dibandingkan dengan kinerja pasar pada periode 2011-2015.

Berdasarkan uraian yang telah dijelaskan, terdapat beberapa rumusan masalah dalam penelitian ini, antara lain sebagai berikut; Apakah terdapat perbedaan kinerja reksadana saham syariah, reksadana syariah pendapatan tetap, reksadana syariah pendapatan campuran dan kinerja pasar Jll dengan menggunakan metode Treynor periode 2011-2015? Bagaimana kinerja reksadana syariah saham, reksadana syariah pendapatan tetap dan reksadana syariah pendapatan campuran dengan menggunakan metode Treynor periode 2011-2015?

Adapun tujuan penelitian ini antara lain; untuk menganalisis perbedaan kinerja reksadana saham syariah, reksadana syariah pendapatan tetap, reksadana syariah pendapatan campuran dan kinerja pasar Jll dengan menggunakan metode Treynor periode 20112015.Untukmenganalisiskinerjareksadanas ahamsyariah, reksadana syariah pendapatan tetap dan reksadana syariah pendapatan campuran?

\section{LANDASAN PUSTAKA}

Menurut Rangkuti dan Ja'far (2012) mendefinisikan reksadana syariah sebagai:

Reksadana yang pengelolaan dan kebijakan investasinya mengacu pada syariah Islam. Reksadana Syariah, misalnya tidak menginvestasikan pada usaha dari saham-saham atau obligasi dari perusahaan yang pengelolaan atau produknya bertentangan dengan syariat Islam. Seperti pabrik makanan atau minuman yang mengandung alkohol, daging babi, rokok dan tembakau, jasa keuangan konvensional, pertahanan dan persenjataan serta bisnis hiburan yang berbau maksiat.

Soemitra (2009:194) menjelaskan terdapat beberapa jenis reksadana syariah yang dipilih oleh investor antara lain sebagai berikut:

1. Reksadana pasar vang syariah, yaitu reksadana yang menginvestasikan dananya pada efek bersifat utang dengan jatuh tempo kurang dari satu tahun. Tujuan reksadana ini ialah untuk menjaga likuiditas dan menjaga modal.

2. Reksadana syariah pendapatan tetap, yaitu reksadana yang melakukan investasi sekurang-kurangnya 80 persen dari aktiva dalam bentuk efek yang bersifat utang. Namun, tingkat resiko yang ditawarkan juga rendah. Reksadana ini memiliki risiko yang relatif lebih besar dari reksadana pasar vang.

3. Reksadana syariah campuran, yaitu reksadana yang dananya diinvestasikan pada saham, obligasi, pasar vang dan sejumlah kas untuk berjaga-jaga. Reksadana ini bertujuan 
Rahma, et al/Jurnal Ekonomi Syariah Teori dan Terapan Vol. 4 No. 5 Mei 2017: 410-423; PERBANDINGAN KINERJA REKSADANA SYARIAH DAN PASAR JII MENGGUNAKAN METODE TREYNOR (Studi Kasus Reksadana Saham Syariah, Reksadana Syariah Pendapatan Tetap dan Reksadana Syariah Pendapatan Campuran Periode 2011-2015)

untuk memperoleh pertumbuhan nilai investasi yang optimal dalam jangka panjang.

4. Reksadana saham syariah, yaitu reksadana yang melakukan investasi sekurang-kurangnya 80 persen dalam efek yang bersifat ekuitas (saham). Jenis ini memiliki tingkat pengembalian yang lebih tinggi dibandingkan dengan yang lain, namun risiko yang diperoleh juga lebih tinggi.

Investor harus mengamati dan menganalisa kinerja suatu reksadana yang akan dipilih sehingga nantinya investor dapat memutuskan untuk tetap menggunakan reksadana tersebut atau mencari yang lain. Kinerja reksadana sangat berkaitan dengan nilai aktiva bersih.

Rangkuti dan Ja'far (2012) mengatakan bahwa Net Asset Value (NAV) atau Nilai Aktiva Bersih (NAB) merupakan alat ukur kinerja reksadana. Nilai Aktiva Bersih berasal dari nilai portofolio reksadana yang bersangkutan. Aktiva atau kekayaan reksadana dapat berupa kas, deposito, SBPU, SBI, surat berharga komersial, saham, obligasi, right dan efek lainnya.

NAB reksadana pada suatu periode dapat dihitung dengan menggunakan persamaan sebagai berikut:

Total NAB=Nilai Aktiva-Total Kewajiban......(1.1)

$N A B$ per unit=

$\frac{\text { Total NAB }}{\text { Total unit penyertaan (saham) diterbitkan ... (1.2) }}$

Dimana:
Total $\mathrm{NAB}=$ Jumlah Nilai Aktiva Bersih pada periode tertentu

NAB Per Unit = Nilai Aktiva Bersih per saham atau unit penyertaan pada periode tertentu.

Evaluasi penilaian kinerja portofolio berkaitan dengan perbandingan return suatu portofolio terhadap portofolio lain. Cara untuk mengetahui evaluasi kinerja suatu portofolio yang mengukur return dan risiko adalah dengan metode Risk Adjusted Return. Tandelilin (2010:494) menjelaskan bahwa dalam Risk Adjusted Return terdapat tiga metode yang sering digunakan, yaitu:

1. Metode Sharpe

Metode Sharpe atau RVAR (Reward to Variability) pertama kali ditemukan oleh William F. Sharpe pada tahun 1996. Manurung (2007:132) mengatakan bahwa metode sharpe menggunakan konsep dari capital market line. Metode ini didasarkan pada apa yang disebut dengan premium atas risiko atau risk premium yang diperoleh dari selisih antara rata-rata kinerja yang dihasilkan oleh reksadana dengan rata-rata kinerja investasi yang bebas risiko (risk free rate). Pengukuran Sharpe membagi risk premium (Rp-RF) dengan standar deviasi portofolio, dimana standar deviasi tersebut merupakan risiko total.

2. Metode Jensen

Metode Jensen pertama kali dikenalkan oleh Michael C. Jensen 
Rahma, et al/Jurnal Ekonomi Syariah Teori dan Terapan Vol. 4 No. 5 Mei 2017: 410-423; PERBANDINGAN KINERJA REKSADANA SYARIAH DAN PASAR JII MENGGUNAKAN METODE TREYNOR (Studi Kasus Reksadana Saham Syariah, Reksadana Syariah Pendapatan Tetap dan Reksadana Syariah Pendapatan Campuran Periode 2011-2015)

pada tahun 1968. Metode ini merupakan metode yang menunjukkan perbedaan antara tingkat return aktual yang diperoleh portofolio dengan tingkat return harapan jika portofolio tersebut berada pada garis pasar modal (Tandelilin, 2010:500). Metode Jensen dapat dikatakan pula sebagai uniquereturn yang dinyatakan sebagai alpha. Apabila alpha bernilai positif, maka kinerja investasi tersebut dapat dikatakan baik.

3. Metode Treynor

Metode Treynor dikemukakan pada tahun 1965 oleh Jack Treynor. indeks ini sering disebut juga dengan reward to volatility ratio. Tandelilin (2010:497) menjelaskan bahwaasumsi yang digunakan oleh Treynor adalah bahwa portofolio sudah terdiversifikasi dengan baik. Pengukuran Treynor menggunakan pembagi volatilitas yang diukur dengan pengukur risiko sistematik atau beta portofolio ( $\beta p)$. Nilai beta merupakan indikator risiko pasar atau risiko sistematis yang berfungsi mengukur derajat kepekaan tingkat keuntungan portofolio terhadap tingkat keuntungan pasar.Indeks Treynor dinyatakan sebagai berikut:

$\mathrm{T}_{\mathrm{pi}}=\frac{\mathrm{R}_{\mathrm{pi}}-\mathrm{Rf}}{\beta_{\mathrm{pi}}}$

Dimana:

$\mathrm{T}_{\mathrm{pi}}=$ Indeks Treynor portofolio $\mathrm{i}$

$\mathrm{R}_{\mathrm{pi}}=$ Rata-rata imbal hasil portofolio $\mathrm{i}$
$\mathrm{Rf}=$ Rata-rata atas bunga invetasi bebas risiko $\beta_{\mathrm{pi}}=$ Beta portofolio i (risiko sitematis) $\mathrm{Rpi}_{\mathrm{p}}-\mathrm{Rf}=$ Premi risiko portofolio $\mathrm{i}$

Pada dasarnya rumus tersebut digunakan untuk menghitung kemiringan (slope) garis yang menghubungkan portofolio yang berisiko dengan bunga bebas risiko. Kemiringan garis dinyatakan dengan pembagian premi risiko dengan beta portofolio. Semakin besar kemiringan garis tersebut berarti semakin baik portofolio yang membentuk garis tersebut.

Untuk menghitung kinerja reksadana syariah dan pasar JII dengan menggunakan metode Treynor, maka dibutuhkan pula beberapa bagian yang perlu dicari terlebih dahulu, antara lain sebagai berikut:

1. Expected Return danRealized Return (Return Realisasi)

Return realisasi merupakan return yang telah terjadi. Return realisasi dapat dihitung memlalui data historis. Return historis ini juga berfungsi sebagai dasar penentuan return ekspektasi dan resiko dimasa mendatang (Hartono, 2010:205).

Return yang digunakan pada penelitian ini adalah rata-rata return bulanan dari tahun 2011 hingga 2015 yang meliputi; return reksadana syariah, JII dan SBIS. Untuk mencari return bulanan reksadana bias didapatkan dengan menggunakan persamaan berikut: 
Rahma, et al/Jurnal Ekonomi Syariah Teori dan Terapan Vol. 4 No. 5 Mei 2017: 410-423; PERBANDINGAN KINERJA REKSADANA SYARIAH DAN PASAR JII MENGGUNAKAN METODE TREYNOR (Studi Kasus Reksadana Saham Syariah, Reksadana Syariah Pendapatan Tetap dan Reksadana Syariah Pendapatan Campuran Periode 2011-2015)

$R_{p}=\frac{\left[\left(N A B_{t}-N A B_{t-1}\right)\right]}{N A B_{t-1}}$

Dimana:

$R_{p}=$ Return reksadana

$\mathrm{NAB}+=$ Nilai Aktiva Bersih pada akhir periode

$\mathrm{NAB}_{\mathrm{t}-1}=$ Nilai Aktiva Bersih pada awal periode

2. Tingkat Pendapatan Bebas Risiko

Tingkat pendapatan bebas risiko pada penelitian ini adalah Sertifikat Bank Indonesia Syariah (SBIS). Data SBIS diperoleh dari situs resmi Bank Indonesia berupa data bulanan yang sudah disesuaikan. Cara mencari tingkat pendapatan bebas risiko dapat dicari dengan menggunakan persamaan sebagai berikut:

SBIS bulanan $=\frac{\text { SBIS Tahunan }}{12}$

3. Tingkat Risiko (Beta)

Hartono (2012:375) menjelaskan bahwa beta merupakan suatu pengukuran volatilitas (volatility) return suatu sekuritas atau return portofolio terhadap return pasar. Perhitungan beta pada penelitian ini menggunakan data bulanan. Beta dihitung dengan melakukan regresi antara return portofolio reksadana sebagai sumbu $Y$ dan return pasar sebagai sumbu $X$.

\section{Hipotesis}

Berdasarkan penjelasan latar belakang, rumusan masalah, tujuan penelitian, tinjauan pustaka, maka hipotesis dalam penelitian ini adalah :

$H_{1}$ : Adanya perbedaan kinerja reksadana saham syariah, reksadana syariah pendapatan tetap, reksadana syariah pendapatan campuran dan kinerja pasar Jll dengan menggunakan metode Treynor periode 2011-2015.

\section{Model Analisis}

Model analisis yang digunakan adalah ANOVAdan uji post hoc LSD. Sebelumnya dilakukan pengujian kinerja reksadana saham syariah, reksadana syariah pendapatan tetap, reksadana syariah pendapatan campuran dan pasar JII yang lebih komperehensif dilakukan dengan melakukan analisis dari hasil perhitungan model risk adjusted performance yaitu metode Treynor. Setelah dilakukan perhitungan dengan menggunakan metode Treynor, dianalisis lebih lanjut menggunakan metode analisis statistik deskriptif.

Selanjutnya dilakukan uji normalitas untuk memenuhi salah satu asumsi uji ANOVA yaitu data yang diteliti merupakan data yang harus terdistribusi normal. Terakhir dilakukan uji ANOVA dan uji post hoc. Uji ANOVA untuk mengetahui perbandingan kinerja reksadana saham syariah, reksadana syariah pendapatan tetap, reksadana pendapatan campuran dan kinerja pasar JII dengan menggunakan metode Treynor periode 2011-2015. Sedangkan uji post hocLSD untuk membandingkan kinerja antar reksadana syariah (saham, pendapatan tetap dan pendapatan campuran) dengan menggunakan metode Treynor periode 2011-2015.

\section{METODOLOGI PENELITIAN}

\section{Pendekatan Penelitian}


Rahma, et al/Jurnal Ekonomi Syariah Teori dan Terapan Vol. 4 No. 5 Mei 2017: 410-423; PERBANDINGAN KINERJA REKSADANA SYARIAH DAN PASAR JII MENGGUNAKAN METODE TREYNOR (Studi Kasus Reksadana Saham Syariah, Reksadana Syariah Pendapatan Tetap dan Reksadana Syariah Pendapatan Campuran Periode 2011-2015)

Pendekatan yang digunakan dalam penelitian ini adalah pendekatan kuantitatif yang bertujuan untuk menjawab masalah yang telah dirumuskan sebelumnya dan memerlukan perhitungan yang bersifat matematis dengan menggunakan rumus statistik tertentu.

\section{Identifikasi Variabel}

Untuk menjawab rumusan masalah dan menguji hipotesis, maka terdapat empat variabel yang digunakan dalam penelitian ini, yaitu; kinerja reksadana saham syariah dengan metode Treynor, kinerja reksadana syariah pendapatan tetap dengan metode Treynor, kinerja reksadana syariah campuran dengan metode Treynor dan kinerja pasar dengan metode Treynor.

\section{Definisi Operasional Variabel}

Untuk memberikan gambaran yang jelas mengenai variabel yang digunakan dalam penelitian ini, maka variabel tersebut dapat didefinisikan sebagai berikut:

1. Kinerja

Kinerja adalah ukuran tingkat pengembalian (return) dari risiko (risk) yang dihasilkan dari suatu portofolio terhadap portofolio lain dengan membandingkan tingkat return yang sama. Tandelilin (2010:489) menjelaskan bahwa:

...kinerja portofolio harus memperhatikan apakah tingkat return portofolio yang diperoleh sudah cukup memadai untuk menutupi risiko yang harus ditanggung.

2. Reksadana Saham Syariah
Reksadana saham syariah, yaitu reksadana yang melakukan investasi sekurang-kurangnya $80 \%$ dari aktiva dalam bentuk efek yang bersifat ekuitas. Reksadana saham termasuk reksadana yang memiliki risiko paling tinggi di antara reksadana yang lain, namun menghasilkan tingkat pengembalian yang tinggi (Manan, 2009:159).

\section{ReksadanaSyariahPendapatanTetap}

Reksadana syariah pendapatan tetap, yaitu reksadana yang melakukan investasi sekurang-kurangnya $80 \%$ dari aktiva dalam bentuk efek yang bersifat utang. Tujuan reksadana ini adalah untuk menghasilkan tingkat pengembalian yang stabil (Manan, 2009:159).

4. Reksadana Syariah Pendapatan

\section{Campuran}

Reksadana syariah pendapatan campuran, yaitu reksadana yang melakukan investasi dalam bentuk efek bersifat ekuitas (saham) syariah dan efek bersifat obligasi syariah (Soemitra, 2009:195).

5. Pasar JII

Pasar pada yang digunakan dalam penelitian ini ialah Jakarta Islamic Index atau JII sebagai pembanding dari kinerja reksadana yang diteliti. Terdapat 30 saham yang tergabung dalam JII dan saham-saham tersebut sudah melalui proses penyaringan (filter) berdasarkan fatwa syariah yang dikeluarkan oleh Dewan Syariah Nasional (DSN).

6. Metode Treynor 
Rahma, et al/Jurnal Ekonomi Syariah Teori dan Terapan Vol. 4 No. 5 Mei 2017: 410-423; PERBANDINGAN KINERJA REKSADANA SYARIAH DAN PASAR JII MENGGUNAKAN METODE TREYNOR (Studi Kasus Reksadana Saham Syariah, Reksadana Syariah Pendapatan Tetap dan Reksadana Syariah Pendapatan Campuran Periode 2011-2015)

Metode Treynor merupakan pengukuran kinerja yang membagi returnlebih portofolio (reward) dengan beta portofolio (Hartono, 2012:645). Metode ini berasumsi bahwa portofolio telah terdiversifikasi dengan baik. Metode Treynor dapat dihitung dengan menggunakan persamaan (1.3).

\section{Jenis dan Sumber Data}

Jenis data yang digunakan dalam penelitian ini adalah data sekunder yang diperoleh melalui publikasi atau data dokumenter yang dipublikasikan maupun tidak dipublikasikan. Data untuk risk free (SBIS) didapatkan dari situs Bank Indonesia, yaitu www.bi.go.id, untuk risk market (JII) didapatkan dari situs ojk.go.id dan untuk NAB dari ketiga reksadana syariah didapatkan melalui situs pusatdata.kontan.com yang diambil periode Januari 2011 - Desember 2015.

\section{Populasi dan Sampel}

Dalam penelitian ini, populasi yang digunakan adalah perusahaan reksadana saham syariah, perusahaan reksadana syariah pendapatan tetap, perusahaan reksadana syariah pendapatan campuran dan pasar Jakarta Islamic Index.

Sampel yang digunakan dalam penelitian ini dilakukan dengan metode purposive samplingyang merupakan suatu teknik penentuan sampel dengan pertimbangan tertentu (Anshori dan Iswati, 2009:105). Sampel yang digunakan adalah perusahaan yang masuk dalam kelompok yang memenuhi kriteria berikut:
1. Reksadana syariah (saham, pendapatan tetapdan campuran) yang sudah tercatat di OJK

2. Reksadana yang selama periode penelitian yaitu dari tahun 2011 sampai 2015 tidak dilikuidasi, tidak bubar, tidak merger, dan tercatat di OJK

3. Sampel yang diambil merupakan produk dari perusahaan reksadana syariah (saham, campuran, dan pendapatan tetap) yang mempublikasikan NAB minimal Januari 2011 sampai dengan Desember 2015 di media cetak

4. Data NAB reksadana syariah (saham, pendapatan tetap dan campuran) yang akan diambil sebagai sampel penulisan ini adalah data bulanan untuk tahun yang bersangkutan.

Dari kriteria tersebut, maka didapatkan sampel sebanyak 21 sampel, yang terdiri dari 7 perusahaan reksadana saham syariah, 7 perusahaan reksadana syariah pendapatan tetap, dan 7 perusahaan reksadana syariah pendapatan campuran.

\section{Teknik Analisis}

Teknik analisis dalam penelitian kuantitatif menggunakan analisis statistik deskriptif. Statistik deskriptif adalah statistik yang digunakan untuk menganalisis data dengan cara mendeskripsikan atau menggambarkan data yang telah terkumpul sebagaimana adanya tanpa bermaksud membuat kesimpulan yang berlaku untuk umum atau generalisasi (Anschori dan Iswati, 2009:116). 
Rahma, et al/Jurnal Ekonomi Syariah Teori dan Terapan Vol. 4 No. 5 Mei 2017: 410-423; PERBANDINGAN KINERJA REKSADANA SYARIAH DAN PASAR JII MENGGUNAKAN METODE TREYNOR (Studi Kasus Reksadana Saham Syariah, Reksadana Syariah Pendapatan Tetap dan Reksadana Syariah Pendapatan Campuran Periode 2011-2015)

1. Melakukan Uji Normalitas

Uji normalitas dilakukan untuk mengetahui apakah data terdistribusi normal. Penelitian yang baik adalah penelitian yang datanya terdistribusi secara normal.

2. Melakukan uji ANOVA pada perhitungan kinerja reksadana syariah dan kinerja pasar dengan menggunakan metode Treynor.

3. Melakukan uji post hoc untuk mengetahui perbedaan kinerja antar reksadana syariah (saham, pendapatan tetap dan campuran) dengan menggunakan metode Treynor.

\section{HASIL DAN PEMBAHASAN}

\section{Uji Norrmalitas}

Penelitian ini membutuhkan uji normalitas dengan menggunakan uji Kolmogorov-Smirnov. Suatu data memenuhi distribusi normal jika memiliki nilai signifikan Kolmogorov-Smirnov lebih dari 0,05. Jumlah observasi lebih dari 30, tidak perlu dilakukan uji normalitas. Sebab, distribusi sampling error term telah mendekati normal (Ajija dkk, 2011:42). Jumlah data observasi yang digunakan dalam penelitian ini adalah sebanyak 60 . Namun untuk mendapatkan hasil yang optimal, maka dihilangkan 10 data yang dianggap tidak wajar atav ekstrim.

Pengujian data yang berdistribusi normal atau tidak dalam penelitian ini dilakukan pada kinerja reksadana saham syariah, reksadana syariah pendapatan tetap, reksadana syariah pendapatan campuran dan kinerja pasar yang telah dihitung dengan menggunakan metode Treynor. Berikut hasil uji normalitas:

Tabel 1.

Hasil UjiNormalitasKolmogorov-Smirnov

\begin{tabular}{|l|c|c|l|}
\hline Jenis Data & $\mathrm{n}$ & Asymp. Sig & Hasil \\
\hline Reksadana Saham Syariah & 50 & 0,091 & Normal \\
\hline $\begin{array}{l}\text { Reksadana Syariah Pendapatan } \\
\text { Tetap }\end{array}$ & 50 & 0,100 & Normal \\
\hline Reksadana Syariah Campuran & 50 & 0,053 & Normal \\
\hline JII & 50 & 0,081 & Normal \\
\hline
\end{tabular}

Sumber: Hasil Penelitian, 2016 (diolah)

Berdasarkan Tabel 4.1 pengujian normalitas dengan metode KolmogorovSmirnov menjelaskan bahwa seluruh hasil pengujian normalitas menunjukan nilai signifikan $>0,05$ yang artinya data kinerja reksadana syariah saham, reksadana syariah pendapatan tetap, reksadana syariah campuran dan kinerja pasar JII memenuhi distribusi normal.

\section{Uji Hipotesis}

Pengujian Hipotesis pada penelitian ini menggunakan uji $F$ (ANOVA) untuk menguji perbedaan kinerja reksadana saham syariah, reksadana syariah pendapatan tetap, reksadana syariah pendapatan campuran dan JII menggunakan metode Treynor. Pada uji F (ANOVA) apabila nilai probabilitas $>0,05$ maka $\mathrm{H}_{0}$ diterima.

Tabel 2.

Hasil Uji ANOVA Kinerja Reksadana Syariah dan Pasar Jll Menggunakan Metode Treynor

\begin{tabular}{l|r|r|r|r|r|} 
& $\begin{array}{c}\text { Sum of } \\
\text { Squares }\end{array}$ & df & $\begin{array}{c}\text { Mean } \\
\text { Square }\end{array}$ & F & Sig. \\
\hline Between Groups & 4.468 & 3 & 1.489 & .151 & .929 \\
\hline Within Groups & 1932.001 & 196 & 9.857 & & \\
\hline Total & 1936.470 & 199 & & & \\
\hline
\end{tabular}

Sumber: Hasil Penelitian, 2016 (diolah)

Pada Tabel 4.2 hasil uji ANOVA data kinerja reksadana saham syariah, reksadana syariah pendapatan tetap, 
Rahma, et al/Jurnal Ekonomi Syariah Teori dan Terapan Vol. 4 No. 5 Mei 2017: 410-423; PERBANDINGAN KINERJA REKSADANA SYARIAH DAN PASAR JII MENGGUNAKAN METODE TREYNOR (Studi Kasus Reksadana Saham Syariah, Reksadana Syariah Pendapatan Tetap dan Reksadana Syariah Pendapatan Campuran Periode 2011-2015)

reksadana syariah pendapatan campuran dan pasar JII menggunakan metode Treynor menghasilkan angka probabilitas 0,929 yang artinya angka tersebut > 0,05 maka $\mathrm{H}_{0}$ diterima. Atau dapat disimpulkan tidak ada perbedaan kinerja antara reksadana saham syariah, reksadana syariah pendapatan tetap, reksadana syariah pendapatan campuran dan pasar JII dengan menggunakan metode Treynor pada tahun 2011 hingga 2015.

Selain menggunakan uji ANOVA, penelitian ini juga menggunakan uji post hoc LSD untuk mengetahui perbedaan antar kelompok. Apabila angka signifikansinya $>0,05$ maka tidak ada perbedaan antar kelompok

Tabel 3.

Hasil UjiPost Hoc LSD

\begin{tabular}{l|l|r|r|r|r|r|}
\hline \multirow{2}{*}{$\begin{array}{l}\text { Kinerja Reksadana } \\
\text { Syariah dan JII } \\
\text { periode 2011-2015 }\end{array}$} & $\begin{array}{c}\text { Mean } \\
\text { Difference }\end{array}$ & Std. Error & Sig. & \multicolumn{2}{|c|}{$95 \%$ Confidence Interval } \\
\cline { 5 - 7 } & & & & $\begin{array}{c}\text { Lower } \\
\text { Bound }\end{array}$ & $\begin{array}{c}\text { Upper } \\
\text { Bound }\end{array}$ \\
\hline \multirow{3}{*}{ RSS } & RSPT & .4000400 & .6279220 & .525 & .838311 & 1.638391 \\
\cline { 2 - 7 } & RSPC & .1389600 & .6279220 & .825 & -1.099391 & 1.377311 \\
\cline { 2 - 7 } & JII & .0839800 & .6279220 & .894 & -1.154371 & 1.322331 \\
\hline \multirow{4}{*}{ RSPT } & RSS & -.4000400 & .6279220 & .525 & -1.638391 & .838311 \\
\cline { 2 - 7 } & RSPC & -.2610800 & .6279220 & .678 & -1.499431 & .977271 \\
\cline { 2 - 7 } & JII & -.3160600 & .6279220 & .615 & -1.554411 & .922291 \\
\hline \multirow{3}{*}{ RSPC } & RSS & -.1389600 & .6279220 & .825 & -1.377311 & 1.099391 \\
\cline { 2 - 7 } & RSPT & .2610800 & .6279220 & .678 & -.977271 & 1.499431 \\
\cline { 2 - 7 } & JII & -.0549800 & .6279220 & .930 & -1.293331 & 1.183371 \\
\hline \multirow{3}{*}{ III } & RSS & -.0839800 & .6279220 & .894 & -1.322331 & 1.154371 \\
\cline { 2 - 7 } & RSPT & .3160600 & .6279220 & .615 & -.922291 & 1.554411 \\
\cline { 2 - 7 } & RSPC & .0549800 & .6279220 & .930 & -1.183371 & 1.293331 \\
\hline
\end{tabular}

Sumber: Hasil Penelitian, 2016 (diolah)

Pada Tabel 4.3 dapat diketahui bahwa seluruh signifikansi > 0,05 yang artinya tidak ada perbedaan yang ditunjukkan antar kelompok periode 2011 2015.

\section{Pembahasan}

Untuk pengujian hipotesis ditemukan hasilnya bahwa tidak ada perbedaan kinerja reksadana saham syariah, reksadana syariah pendapatan tetap, reksadana syariah campuran dan pasar JII menggunakan metode Treynor periode 2011 hingga 2015. Hal ini ditunjukkan setelah dilakukannya uji $f$ (ANOVA) dengan adanya nilai signifikansi yang lebih besar (>) dari 0,05 yang berarti bahwa $H_{0}$ diterima dan $H_{1}$ ditolak. Sedangkan dari uji post hoc dapat dikatakan bahwa tidak ada perbedaan antar reksadana syariah (saham, pendapatan tetap dan campuran). Namun apabila dilihat melalui angka, didapatkan hasil angka yang berbeda tiap-tiap reksadananya.

Tidak adanya perbedaan kinerja tersebut juga dapat dilihat setelah melakukan penghitungan return dari tiaptiap reksadana dan JII. Tinggi rendahnya return tidak dapat menjadi jaminan suatu portofolio memiliki kinerja yang bagus. Terdapat beberapa variabel yang berpengaruh dalam mengevaluasi kinerja. Salah satunya adalah risiko.

Risiko dalam perhitungan Treynor ditentukan oleh beta dimana beta sebagai pembagi juga sangat berperan penting dan mempengaruhi return. Biasanya return yang tinggi diiringi pula dengan risiko yang tinggi. Hal tersebut sesuai dengan konsep high risk high return. Konsep risk maupun return tidak dapat dipisahkan dan saling berkaitan antar satu dengan lainnya.

Tandelilin (2010:101) menyebutkan bahwa dalam konteks investasi, keuntungan di masa datang mencerminkan harapan yang belum 
Rahma, et al/Jurnal Ekonomi Syariah Teori dan Terapan Vol. 4 No. 5 Mei 2017: 410-423; PERBANDINGAN KINERJA REKSADANA SYARIAH DAN PASAR JII MENGGUNAKAN METODE TREYNOR (Studi Kasus Reksadana Saham Syariah, Reksadana Syariah Pendapatan Tetap dan Reksadana Syariah Pendapatan Campuran Periode 2011-2015)

tentu terealisasi. Dalam Islam, dijelaskan pula bahwa return merupakan ketentuan dari Allah SWT. Seperti yang dijelaskan dalam Al Quran pada surat Al-Baqarah 245 yang artinya:"Siapakah yang mau memberi pinjaman kepada Allah, pinjaman yang baik (menafkahkan hartanya di jalan Allah), maka Allah akan melipat gandakan pembayaran kepadanya dengan lipat ganda yang banyak. Allah menyempitkan dan melapangkan (rezeki). Kepada-Nya-lah kamu dikembalikan."

Quthb (2000:315) menafsirkan ayat tersebut sebagai berikut:

"Harta tidak akan lenyap karena diinfakkan. Harta itu tersimpan di sisi-Nya. Dia melipatgandakannya dengan lipat ganda yang banyak. Dia melipatgandakannya di dunia berupa kekayaan, berkah, kebahagiaan, dan kegembiraan. Dia juga melipatgandakannya berupa nikmat, kesenangan, keridhaan, dan kedekatan kepada Allah. Oleh karena itu, tidak perlu takut kepada mati dan kemiskinan karena tidak ada yang dapat lolos dari kembali kepada Allah. Karena itu, hendaklah orang-orang mukmin berjihad di jalan Allah, mempertaruhkan nyawa dan harta. Hendaklah mereka yakin bahwa napasnya sudah dihitung dan rezekinya sudah ditentukan."

Ayat diatas menjelaskan secara jelas bahwa Allah SWT akan melipatgandakan kekayaan yang dimiliki umat-Nya apabila mereka berjihad di jalan Allah SWT. Salah satunya adalah bermuamalah dengan menggunakan ketentuan dari Allah dan niat sematamata karena mengharap ridho dari Nya. Ayat ini juga menjelaskan kepada manusia bahwa setiap rezeki sudah ditentukan dan tidak ada yang mengetahuinya kecuali Allah SWT.

Tabel 4.

Rata - rata Return Reksadana Syariah dan Jll Tahun $2011-2015$

\begin{tabular}{|c|c|c|c|c|c|c|}
\hline & \multicolumn{5}{|c|}{ Tahun } & \multirow{2}{*}{$\begin{array}{l}\text { Rata- } \\
\text { rata }\end{array}$} \\
\hline & 2011 & 2012 & 2013 & 2014 & 2015 & \\
\hline Reksadana Saham Syariah & -0.135 & 1.055 & -0.252 & 1.833 & -1.58 & 0.184 \\
\hline Reksadana Syariah Pendapatan Tetap & 1.241 & 0.619 & -0.073 & 0.553 & 0.433 & 0.555 \\
\hline Reksadana Syariah Campuran & 0.254 & 0.953 & -0.186 & 1.356 & -0.187 & 0.438 \\
\hline Pasar Saham JII & 2.127 & 1.502 & 0.082 & 1.291 & -0.882 & 0.824 \\
\hline
\end{tabular}

Sumber: Hasil Penelitian, 2016 (diolah)

Tabel 5.

Rata - rata Beta Reksadana Syariah Tahun

$2011-2015$

\begin{tabular}{|l|l|}
\hline & Rata-rata \\
\hline Reksadana Saham Syariah & 0,897 \\
\hline Reksadana Syariah Pendapatan Tetap & 1,459 \\
\hline Reksadana Syariah Pendapatan Campuran & 1,238 \\
\hline Pasar Saham JII & 1 \\
\hline
\end{tabular}

Sumber: Hasil Penelitian, 2016 (diolah)

BerdasarkanTabel 4.4 dapat dilihat

bahwa rata - rata return tertinggi periode 2011-2105 dimiliki oleh pasar JII, yaitu sebesar 0,824. Unggulnya return pasar JII dikarenakan banyak investor yang masih berinvestasi di JII karena mereka beranggapan bahwa return yang didapat untuk beberapa tahun kemudian masih tergolong tinggi. Penyebab yang lainnya adalah kurangnya informasi mengenai reksadana syariah oleh investor sehingga reksadana syariah belum mendapat hati ataupun belum mendapat kepercayaan investor sebagai wadah untuk berinvestasi. Kemudian kinerja yang unggul setelahnya adalah reksadana syariah pendapatan tetap sebesar 0,555, reksadana syariah pendapatan campuran sebesar 0,438 dan yang paling rendah adalah reksadana saham syariah yaitu sebesar 0,184. 
Rahma, et al/Jurnal Ekonomi Syariah Teori dan Terapan Vol. 4 No. 5 Mei 2017: 410-423; PERBANDINGAN KINERJA REKSADANA SYARIAH DAN PASAR JII MENGGUNAKAN METODE TREYNOR (Studi Kasus Reksadana Saham Syariah, Reksadana Syariah Pendapatan Tetap dan Reksadana Syariah Pendapatan Campuran Periode 2011-2015)

Pada tahun 2013, return reksadana syariah bernilai negatif dan JII juga memiliki return yang rendah. Hal tersebut dikarenakan terjadinya kondisi ekonomi yang tidak menentu, seperti terjadinya inflasi dan penurunan kurs mata uang pada saat itu. Tidak hanya terjadi pada tahun 2013 saja, pada tahun 2015 return reksadana syariah dan JII memiliki nilai yang kecil. Penyebab menurunnya return tersebut adalah terjadinya Jokowi effect dan adanya penurunan kurs mata uang rupiah sehingga berdampak pula pada investor yang berinvestasi. Investor cenderung menarik uangnya dari pasar untuk menghindari kerugiaan. Namun apabila dilihat secara keseluruhan, ratarata return selama 5 tahun terakhir terbilang baik karena tidak menunjukkan nilai negatif, baik untuk reksadana syariah maupun pasar JII.

Sedangkan pada Tabel 4.5 menunjukkan bahwa rata-rata beta yang tertinggi dimiliki oleh reksadana syariah pendapatan tetap sebesar 1,459. Hal tersebut sesuai karena reksadana syariah jenis pendapatan tetap memang memiliki risiko yang tinggi bila dibandingkan dengan reksadana lainnya. Beta pasar bernilai 1 karena menjadi acuan penilaian pada reksadana syariah. Sesuai hasil perhitungan pada Tabel 4.5, dapat dikatakan pula bahwa reksadana syariah pendapatan tetap dan reksadana pendapatan campuran memiliki risiko yang lebih tinggi dari pasar Jll yang artinya berinvestasi di kedua jenis reksadana tersebut lebih berisiko dibandingkan berinvestasi di pasar JII.

Tabel 6.

Perhitungan Rata - rata Kinerja

Reksadana Syariah dan pasar JII Menggunakan Metode Treynor periode 2011- 2015

\begin{tabular}{|c|c|c|c|c|c|c|}
\hline & \multicolumn{5}{|c|}{ Tahun } & \multirow{2}{*}{$\begin{array}{c}\text { Rata- } \\
\text { rata }\end{array}$} \\
\hline & 2011 & 2012 & 2013 & 2014 & 2015 & \\
\hline Reksadana Saham Syariah & $-0,730$ & 0.788 & $-0,949$ & 1.537 & -1.940 & -0.259 \\
\hline Reksadana Syariah Pendapatan Tetap & 0,548 & .1 .222 & 0,268 & $0,0,047$ & 0,040 & 0,0206 \\
\hline Reksadana Syariah Campuran & 0.232 & 0.441 & 0,635 & 0.784 & 0.930 & 0.115 \\
\hline Pasar Saham JII & .0 .329 & 0.575 & .0 .538 & 0.830 & .1 .576 & .0 .208 \\
\hline
\end{tabular}

Sumber: Hasil Penelitian, 2016 (diolah) BerdasarkanTabel

dapatdilihatbahwa rata-rata kinerja reksadana syariah yang meliputi; saham, pendapatan tetap dan pendapatan campuran dan pasar JII menunjukkan angka negatif selama 5 tahun terakhir. Rata-rata kinerja reksadana syariah pendapatan campuran unggul dibandingkan dengan kinerja reksadana yang lain dengan angka $-0,115$. Bahkan kinerja pasar Jll dapat dikalahkan pula oleh kinerja reksadana tersebut.

Unggulnya reksadana syariah pendapatan campuran dapat dikarenakan rata-rata return yang tidak terlalu rendah dan tidak terlalu tinggi pula apabila dibandingkan dengan yang lain. Akan tetapi, risiko yang diperoleh tidak setinggi reksadana syariah pendapatan tetap. Sehingga apabila dihitung kinerja reksadananya, return yang tidak terlalu rendah dengan risiko yang kecil dapat meningkatkan kinerja reksadana syariah pendapatan campuran. Selain itu, reksadana syariah pendapatan 
Rahma, et al/Jurnal Ekonomi Syariah Teori dan Terapan Vol. 4 No. 5 Mei 2017: 410-423; PERBANDINGAN KINERJA REKSADANA SYARIAH DAN PASAR JII MENGGUNAKAN METODE TREYNOR (Studi Kasus Reksadana Saham Syariah, Reksadana Syariah Pendapatan Tetap dan Reksadana Syariah Pendapatan Campuran Periode 2011-2015)

campuran tidak menempatkan dananya di satu tempat saja melainkan di berbagai tempat (diversifikasi). Sehingga apabila melihat hasil perhitungan pada Tabel 4.6 dapat dikatakan pula bahwa penempatan dana di berbagai investasi dapat menghasilkan kinerja yang lebih baik dibandingkan hanya menempatkan dana investasi di satu tempat saja.

Akan tetapi, apabila dilihat secara keseluruhan rata-rata kinerja reksadana syariah dan pasar JII mengalami fluktuatif naik turun dari tahun 2011 hingga 2015. Berdasarkan hasil perhitungan perbandingan kinerja ketiga jenis reksadana syariah dan pasar JII pada Tabel 4.6 menjelaskan bahwa perhitungan rata - rata kinerja reksadana syariah menggunakan metode Treynor per bulan tertinggi berada pada tahun 2014 reksadana saham syariah yaitu sebesar 1,537. Akan tetapi, pada tahun 2015 , kinerja pada reksadana saham syariah mengalami penurunan drastis sehingga mencapai angka terendah yaitu -1,940. Angka tersebut sekaligus menjadi rekor sebagai nilai kinerja terburuk reksadana syariah dan pasar Jll selama 5 tahun terakhir.

Setelah reksadana syariah pendapatan campuran, kinerja terbaik selanjutnya dicapai oleh reksadana syariah pendapatan tetap sebesar -0,206. Kemudian disusul dengan kinerja pasar JII yang berbeda tipis yaitu sebesar- 0,208 dan untuk rata-rata kinerja terburuk di antara yang lain adalah reksadana saham syariah dengan nilai -0,259.
Berdasarkan uji ANOVA yang telah dilakukan, dapat diketahui bahwa kinerja reksadana saham syariah, reksadana syariah pendapatan tetap, reksadana syariah pendapatan campuran dan kinerja pasar JII dengan menggunakan metode Treynor periode 2011-2015 terbukti tidak memiliki perbedaan karena nilai signifikansinya > 0,05. Meskipun tidak memiliki perbedaan kinerja, namun apabila melihat hasil uji post hoc, terdapat perbedaan angka yang dapat dilihat melalui mean difference-nya, baik dari reksadana saham syariah, reksadana syariah pendapatan tetap, reksadana syariah pendapatan campuran dan pasar JII.

\section{SIMPULAN}

1. Hasil pengujian uji $F$ (ANOVA) didapatkan bahwa tidak ada perbedaan kinerja antara reksadana saham syariah, reksadana syariah pendapatan tetap, reksadana syariah pendapatan campuran, dan pasar JII menggunakan Metode Treynor pada tahun 2011, 2012, 2013, 2014 dan 2015.

2. Berdasarkan hasil perhitungan rata rata kinerja reksadana saham syariah, reksadana syariah pendapatan tetap dan reksadana syariah pendapatan campuran dengan menggunakan metode Treynor dari tahun 2011 hingga 2015, reksadana syariah pendapatan campuran terbukti memiliki kinerja yang paling baik dibandingkan dengan yang lainnya. Reksadana ini memiliki perhitungan rata-rata kinerja yang 
Rahma, et al/Jurnal Ekonomi Syariah Teori dan Terapan Vol. 4 No. 5 Mei 2017: 410-423; PERBANDINGAN KINERJA REKSADANA SYARIAH DAN PASAR JII MENGGUNAKAN METODE TREYNOR (Studi Kasus Reksadana Saham Syariah, Reksadana Syariah Pendapatan Tetap dan Reksadana Syariah Pendapatan Campuran Periode 2011-2015)

dihitung dengan metode Treynor yaitu sebesar $-0,115$.

\section{DAFTAR PUSTAKA}

Ajija, Shochruldkk. 2011. Cara CerdasMenguasaiEViews. Jakarta: SalembaEmpat

Anschori, Muslich dan Sri Iswati. 2009. Metodologi Penelitian Kuantitatif. Surabaya: Universitas Airlangga Press

Anshori, Abdul Ghofur. 2008. Aspek Hukum Reksa Dana Syariah di Indonesia. Bandung: PT Refika Aditama

Bi.go.id (diakses pada 18 Maret 2016)

Dzajuli, A. 2006. Kaidah - Kaidah Fikih: Kaidah - Kaidah Hukum Islam dalam Masalah - Masalah yang Prakris. Jakarta: Kencana

Hartono, Jogiyanto. 2012. Teori Portofolio dan Analisis Investasi. Yogyakarta: BRFEYogyakarta

Manan, Abdul. 2009. Aspek Hukum Dalam Penyelenggaraan Investasi di Pasar Modal Syariah Indonesia. Jakarta: Kencana Prenada Media Group

Manurung, Adler Haymans. 2007. Panduan Lengkap Reksa Dana Investasiku. Jakarta: PT Kompas Media Nusantara

Ojk.go.id (diakses 18 Maret 2016)

Pusatdata.kontan.com (diakses pada 2 April 2016)

Quthb, Sayyid. 2000. Tafsir Fi Zhilalil Qur'an di Bawah Naungan Al-Qur'an. Jilid 1. Jakarta: Gema Insani Press

Rangkuti, Latifah dan Hotmal Ja'far. 2012. Analisis Faktor-Faktor yang Mempengaruhi Pertumbuhan dan Perkembangan Reksa Dana Syariah (Islamic Mutual Fund) di Indonesia Sampai Dengan Tahun 2012. Tidak diterbitkan. Medan Fakultas Ekonomi Universitas Sumatera Utara

Soemitra, Andri. 2009. Bank dan Lembaga Kevangan Syariah. Jakarta: Kencana Prenada Media Group

Sugiyono, 2010. Metode Penelitian Kuantitatif, Kualitatif, dan R\&D. Bandung: Alfabeta

Tandelilin, Eduardus. 2010. Portofolio dan Investasi. Yogyakarta: Kanisius 